Espaço Aberto | Open Space

\title{
"A mudança social se desenrola conflituosamente no terreno da linguagem": entrevista com Monica Heller (Professora da University of Toronto)
}

"Social change plays out conflictively on the terrain of language": interview with Monica Heller (University of Toronto professor)

Ruben George Oliven*

* Universidade Federal do Rio Grande do Sul - Porto Alegre, RS, Brasil ruben.oliven@gmail.com

https://orcid.org/0000-0003-3556-6955

Pedro de Moraes Garcez ${ }^{* *}$

** Universidade Federal do Rio Grande do Sul - Porto Alegre, RS, Brasil pedrom.garcez@ufrgs.br https://orcid.org/0000-0001-8642-678X 


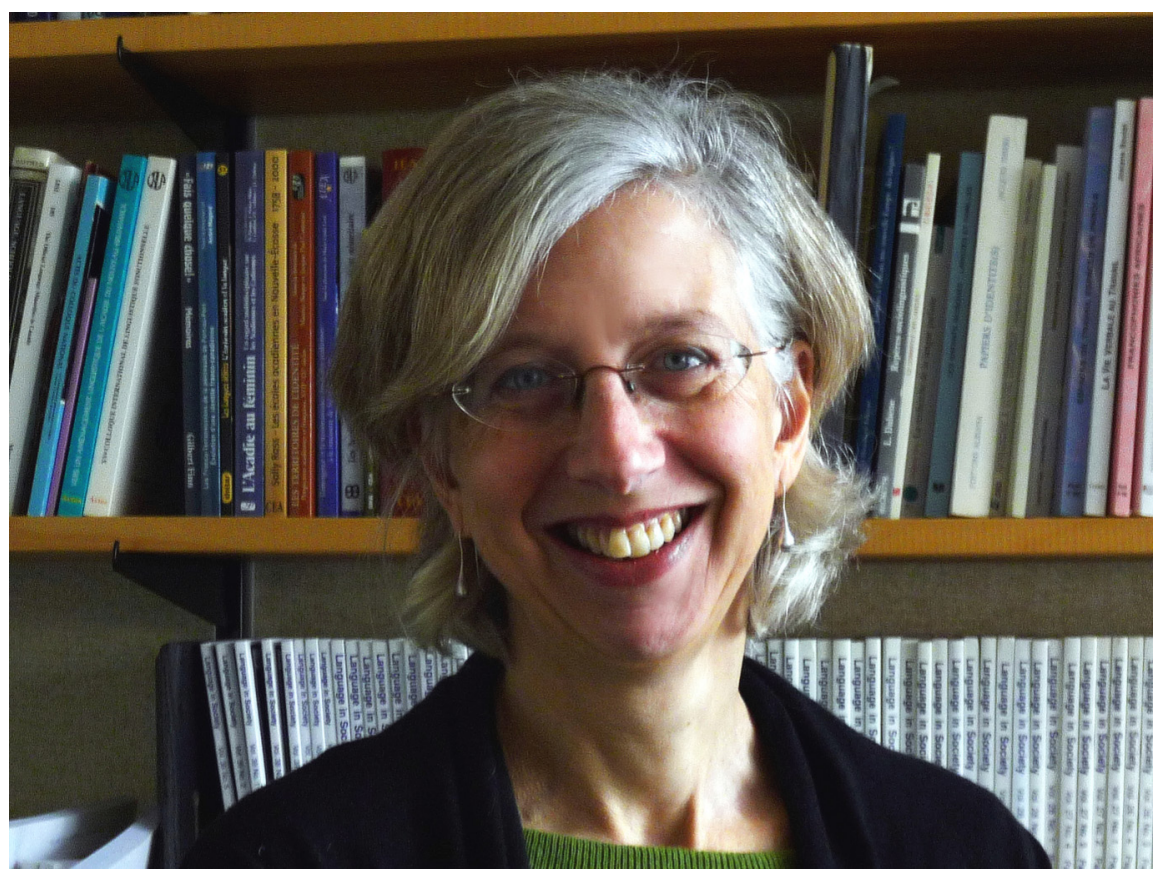

Monica Heller. Foto: Christine Connelly, 2012

\section{Introdução}

Monica Heller é professora titular da University of Toronto, Canadá, onde atua nos departamentos de Antropologia e de Educação em Justiça Social do Ontario Institute for Studies in Education (OISE). Foi presidente da Associação Norte-Americana de Antropologia (2013-2015) e desde 2017 é editora-chefe do Journal of Sociolinguistics. É expoente nos estudos da linguagem em Antropologia e Linguística. Em abril de 2019, as publicações mais recentes de Heller sobre a linguagem na nova economia globalizada (Heller, 2011; Heller; Duchêne, 2012; Heller; McElhinny, 2017; Heller et al., 2016) foram objeto do curso livre de pós-graduação "Linguagem, colonialismo, capitalismo: rumo ao pós-nacionalismo", oferecido pelo Programa de Pós-Graduação em Letras da UFRGS. Nessa ocasião, ela participou também de atividades junto ao Programa de Pós-Graduação em Antropologia Social da UFRGS, onde proferiu palestra sobre o quadro amplo da 
sua obra e sobre sua atuação como liderança acadêmica nas áreas da Antropologia e dos estudos da linguagem que, em configurações acadêmicas da América do Norte, são praticadas sob o nome de Antropologia Linguística. Nessas atividades, a visita da Profa. Monica ensejou rara oportunidade de intersecção entre Antropologia e Linguística, aprofundada na entrevista que segue.

\section{Entrevista}

Ruben Oliven: Monica, você poderia nos falar um pouquinho sobre a sua formação, sobre a sua formação familiar, o que levou você a entrar para a Antropologia, em particular a Antropologia Linguística. Como isso se passou?

Monica Heller: Sim, basicamente a história é que eu cresci em Montreal, Québec, uma cidade multilíngue, dividida principalmente entre inglês e francês, com uma longa história de colonialismo que não vou abordar agora, mas onde diferenças linguísticas são realmente importantes na vida cotidiana. Quando eu era criança, era um momento de mudança social, e todo o mundo estava brigando por causa de língua, e todo o mundo andava nervoso: "Quando eu vou ao centro, quando eu entro no ônibus, quando eu abro a boca, devo falar inglês? Devo falar francês?" "Como é que eu falo os dois?" Pois é, a mudança social estava se desenrolando conflituosamente no terreno da linguagem. Cada lado tinha a sua história, mas a minha família, não. Nós não fazemos parte dos principais grupos de atores, e de fato éramos periféricos. Bom, muitos antropólogos são pessoas marginais, certo? E eu não sou exceção. A gente não pertencia propriamente a nenhuma comunidade, mas falava as línguas em questão. Então, a gente escutava os falantes de francês contando a história deles, e fazia sentido; escutava os falantes de inglês contando a história deles, que era em completa contradição, também fazia sentido da perspectiva deles. Esse foi em parte um momento em que eu me perguntava "o que está se passando aqui?". Como explicar isso, dado que ninguém tem uma história coerente para explicar o que está acontecendo. E por que todo o mundo tem tanta certeza de que está certo? Mas ninguém consegue escutar? E aí o meu pai veio para casa um dia - ele gostava de frequentar bancas de revistas - com uma manchete sobre Noam Chomsky, que era grande coisa nos anos 1960, e ele me disse: "Olha, tem 
essa coisa chamada Linguística, e você fica aí, sabe, falando de..." - ele devia saber que eu andava obcecada com aquilo. Eu pensei: "Mm!" Quando fui para a faculdade, na verdade nos Estados Unidos, não tinha curso de Linguística, mas ainda assim tinha uma ênfase em Linguística, e tinha alguém no Departamento de Sociologia e Antropologia que...

\section{Ruben Oliven: Isso foi no Swarthmore College?}

Monica Heller: Sim, no Swarthmore College, perto da Filadélfia. Era um departamento conjunto de Sociologia e Antropologia, eles enfatizavam muito "queremos borrar as divisas, não queremos fazer distinção entre as duas". Bom, enfim, tinha alguém que dava uma disciplina de Sociolinguística, e eu pensei "mmm, isso parece... alguma coisa". Nem estava sendo oferecida naquele semestre, mas eu convenci o pessoal a abrir uma turma para um pequeno grupo, como disciplina de leituras dirigidas. Então a minha graduação foi em Sociologia e Antropologia, com uma ênfase menor em Linguística, porque eu estava buscando as ferramentas para entender de onde eu vinha e a história que ainda estava se passando, e mais amplamente - bem, estes termos que eu uso hoje, àquela altura eu não tinha - a relação entre o papel da linguagem no estabelecimento da diferença social e da desigualdade social. E era nos Estados Unidos, lá funcionava diferente. Ninguém jamais explica nada para os canadenses nos EUA, porque eles acham que a gente é americano. É só quando você comete um erro que todo o mundo para e diz: "O quê? o quê?? quê - por que você disse isso?" Então é difícil de compreender esse tipo de coisa meio implícita, mas claramente não estava funcionando do mesmo modo como eu estava acostumada. Mas à altura eu já estava terminando a graduação. Também eu trabalhava no verão, sabe, para ganhar dinheiro para a faculdade, num ambulatório num hospital no centro de Montreal. As instituições se dividem entre católico-francês e protestante-inglês, em geral, mas as pessoas podiam procurar lugares nos quais não pertenciam, e essa instituição era bem no centro, e a gente recebia pacientes, e funcionários, de toda parte. Então eu passava os verões de certo modo observando este embate: trabalhando no agendamento de consultas, as pessoas vinham e olhavam para mim e não falavam, porque temiam falar a língua errada. E assim eu tinha que primeiro - bom, eles tinham fichas da clínica com os nomes, e você tentava adivinhar da ficha qual seria a língua certa, 
mas, claro, tinha muitos casamentos, especialmente entre católicos irlandeses e italianos e católicos franceses, e aparecia uma pessoa com um nome como, sabe, Michelle Ryan e ih - você sempre ia errar... Então a gente continuava seguindo essa história. E, à altura que eu ia terminando os estudos de graduação, eu meio que me dei conta, "puxa, isso é realmente interessante", e eu queria fazer... - mas é preciso lembrar que gramática gerativa, que era então a corrente principal da Linguística - que era interessante de, e muito divertido de fazer exercícios, de ir da estrutura profunda para a estrutura de superfície e da estrutura de superfície para a estrutura profunda, tipo fazer quebra-cabeça, álgebra, algo assim, sudoku... - que eu queria seguir para a pós-graduação. Eu não estava pronta. Mas, no Canadá, havia só um único lugar em que alguém teria alguma ideia sobre essas coisas de língua e sociedade, que era em Montreal. Então você provavelmente iria acabar lá, mesmo que a abordagem fosse muito estruturalista, muito formalista, e as pessoas que trabalhavam lá só estavam trabalhando com o francês. Então era um tipo de momento de usar a Sociolinguística para legitimar a variedade de francês do Québec em relação ao francês europeu, mas também de fazer da nossa língua uma parte da construção da nossa nação, da nação québécoise, e eu estava interessada em processos de fronteira. Eu estava interessada em... bom, de dentro, dava para ver a construção da fronteira, mas eu queria saber o que acontecia, quem era incluído, quem era excluído e com base em quais critérios, e sobre isso ninguém estava trabalhando. Havia dois lugares nos Estados Unidos onde havia uma abordagem que me daria algo assim: Stanford e Berkeley. Eu pensava, sabe, "eu nunca vou conseguir entrar; eu decerto vou para Montreal". A professora em Montreal, Gillian Sankoff, foi maravilhosa e me ajudou muito na minha carreira de pós-graduação. Ela disse: "Olha, vem, a gente não vai poder treinar você, mas eu deixo você - eu entendo o que você está querendo fazer e eu vou deixar você fazer isso." Então eu achava que era lá que eu ia parar, e que nem Stanford e nem Berkeley iam me aceitar, mas fui aceita em Berkeley. E então eu fui. Então o que eu decidi fazer -

Ruben Oliven: Essa professora estava no Canadá?

Monica Heller: Sim, a professora me ajudando estava no Canadá, na Université de Montréal. 


\section{Ruben Oliven: OK.}

Monica Heller: Gillian Sankoff.

Pedro Garcez: Que é uma sociolinguista bastante conhecida hoje.

Monica Heller: É.

Pedro Garcez: Ela era conhecida então?

Monica Heller: Era o começo da fama dela, digamos, porque àquela altura ela estava colaborando proximamente com William Labov, e assim havia esse pequeno grupo de pessoas entre a Filadélfia e Montreal que estavam começando a publicar juntas... Então, sabe, àquela altura, o trabalho que ela tinha começado, como projeto, ela começou em 1970, o que, pelo final dos 1970, dava a ela... sim, ela era bem conhecida.

Pedro Garcez: E ela era linguista, mas ela era também antropóloga, não era?

Monica Heller: Certo, de fato, o trabalho inicial dela foi na Papua Nova Guiné, e ela se interessou pelo tok pisin, foi assim que ela passou a se interessar pelo crioulo da Papua Nova Guiné, e foi assim que ela passou a se interessar por linguagem, eu acho. E o departamento em que ela estava lecionando na Université de Montréal era, e é, um departamento de quatro campos, ${ }^{1 . . .}$ - minha mãe voltou para a faculdade quando eu tinha nove anos para fazer mestrado em Sociologia e esteve numa disciplina com a Gillian. Minha mãe disse: "Vai e fala com a Gillian Sankoff..." Foi assim que tudo isso... Então ela deve ter feito algo pelas Ciências Sociais em algum ponto, talvez na graduação ou mestrado. Mas ela era de fato "a" antropóloga da linguagem no Departamento de Antropologia, mas trabalhando com Henrietta Cedergren, que vinha trabalhando - ela é do Panamá, eu acho - sobre crioulos do Caribe, e ela

1 Tradicionalmente os departamentos de Antropologia de universidades norte-americanas e canadenses têm os seguintes quatro campos de estudo e pesquisa: Arqueologia, Antropologia Biológica, Antropologia Linguística e Antropologia Sociocultural. 
estava no Departamento de Linguística da Université du Québec à Montréal. Então Cedergren e Sankoff estavam trabalhando juntas. O marido de Sankoff, David Sankoff, era matemático, e ele começou a se interessar por versões.. matemáticas. Então isso foi...

Pedro Garcez: Modelagem.

Monica Heller: Modelagem. Então, eu creio que, entre ele e Labov, houve uma virada para uma abordagem mais formalista estruturalista, diferente daquela com que a Gillian tinha começado, mas que ela então seguiu.

Então, eu apareci em Berkeley. Decidi que, porque o meu curso de graduação, a minha formação, era mais em Sociologia e Antropologia, e, se eu queria realmente entender essa coisa de língua e entender essas ferramentas, eu ficaria melhor fazendo o trabalho de pós-graduação na Linguística e cursando disciplinas na Antropologia do que o inverso, porque eu não confiava em mim mesma para, se estivesse na Antropologia, cursar disciplinas na Linguística, porque, você sabe, eles são mais técnicos, e tem sempre montes de histórias interessantes na Antropologia, e eu sempre ia achar razões. Então fui para a Linguística, sabendo, contudo, que havia gente em Antropologia e também em Psicologia, na verdade - Susan Ervin-Trip foi a mais importante - e no fim das contas também em Filosofia, um cara chamado John Searle era famoso pelo trabalho sobre atos de fala. Era de certo modo um momento interdisciplinar, de modo que você podia entrar em qualquer um daqueles departamentos e acabar trabalhando com eles. E aí a certa altura o chefe do meu departamento, de Linguística, Chuck Fillmore, um cara impressionante, conhecido pelo trabalho em Pragmática, que é - então tem essas pessoas em Berkeley, a outra razão - perdão, eles eram refugiados de Noam Chomsky. Teve toda esta grande briga em Linguística nos anos 1970 sobre significado, basicamente, se a questão de produção de significado era uma questão própria para linguistas, e a posição de Chomsky era de que não era. E havia linguistas que discordavam dele, e esses foram banidos para a Califórnia, para a Costa Oeste, e estavam nesse departamento. Isso era outra razão para ir para aquele departamento. Então Chuck me chama no escritório e me diz: "Será que você está no departamento certo? Eu acho que você devia estar na Antropologia." E isso, é claro, foi devastador, porque, claro, ele era provavelmente a pessoa mais esperta que eu jamais 
tinha conhecido, e eu adorava ele... Mas eu fui falar com o pessoal na Antropologia. Eu já estava trabalhando com John Gumperz, que também tinha uma dessas - ele começou em Linguística Germânica, como dialetólogo, acabou trabalhando com multilinguismo na Índia, então acho que foi contratado inicialmente em Estudos Asiáticos em Berkeley, Linguística, e acabou na Antropologia. Esse vai ser um refrão que você vai escutar muito: negócio bagunçado, que não se encaixa bem nas categorias disciplinares conforme elas se desenvolveram na América do Norte à época. E, se vocês quiserem, mais adiante podemos falar mais sobre isso. Acho que há razões para tanto, sobre as quais podemos falar. No fim as pessoas que me atraem são as que não se encaixam. Então eles disseram: "Sabe, Monica, na verdade, fique onde você está. Você pode fazer o que quiser e você provavelmente vai ter mais chances de conseguir emprego com um título em Linguística do que em Antropologia." Eu não tinha certeza de que isso fosse verdade. Talvez fosse. É inteiramente possível, mas não em departamentos de Linguística. Nenhuma das pessoas, nenhum dos outros estudantes de pós-graduação na minha coorte terminaram em departamentos de Linguística. O único tipo de sócio-qualquer-coisa a ver com linguagem que é compreensível nos departamentos de Linguística na América do Norte é esse tipo variacionista mais formalista de que eu falava antes, e mesmo assim, nem sempre esse é o caso necessariamente. Então eu fiz o meu mestrado, e era um programa em que eles podiam reprovar você no mestrado se as coisas estivessem indo mal, mas, se não fosse esse o caso, a gente ficava. Então eu fiz o meu mestrado e o doutorado em Berkeley, mas com pesquisa em Québec. Assim eu ia e voltava. Passei um semestre a certa altura estudando com Gillian Sankoff na Université de Montréal, de certo modo fazendo parte do grupo dela também e recebendo treinamento naquela abordagem também. Fiz um estágio na agência de serviço público responsável pela implementação das políticas linguísticas em Québec, e assim aprendi muito sobre aquilo tudo. Era um momento em que eles estavam trabalhando muito para estabelecer laços internacionais com outras regiões onde havia questões de políticas linguísticas e assim mandavam delegações para a Catalunha, ou a Bélgica. Estavam muito interessados em Israel naquele momento, com a padronização do hebraico. Portanto, era um momento interessante, um momento interdisciplinar interessante. Eu não tinha necessariamente a ideia de que queria ter uma carreira acadêmica. Não era por isso que eu estava fazendo aquilo. $\mathrm{Na}$ 
verdade eu achava que ia acabar trabalhando no setor público, provavelmente, ou numa organização não governamental ou algo assim. Mas daí, porque todo o mundo estava fazendo aquilo, quando eu estava terminando a minha tese, me candidatei aos empregos acadêmicos que estavam circulando, e me foi oferecido um emprego na Luisiana. Fui lá para a entrevista de emprego. A comida era fantástica! As questões eram interessantes, extremamente interessantes. Há maneiras em que eu ainda não entendo as intersecções entre linguagem e raça, e gênero e classe na Luisiana, e o colonialismo. Tão interessante! Eu teria estado interessada, sabe, intelectualmente, mas eu vi tanta gente com suportes para armas nas picapes! E aquilo me deixou meio nervosa, e toda aquela conversa que havia nos Estados Unidos à época sobre segurança, sobre "tenha cuidado, tenha cuidado". Em Berkeley naquela época estava ficando muito cansativo, como mulher, como uma mulher jovem, ter que ficar resolvendo a todo instante "será que eu posso ir a esse evento no campus que vai terminar depois de escurecer?" e "como é que eu vou voltar?". E eu estava meio cansada daquilo. E de certo modo eu me dei conta de que eu não queria ter o meu emprego acadêmico aqui e o meu trabalho de campo em algum lugar distante. Eu queria que as coisas fossem mais coesas. E o que eu realmente conhecia e de certo modo o que importava para mim estava no Canadá. Então, me perdoem, mas as questões americanas, ainda que intelectualmente interessantes, não eram... o meu coração não estava ali. Então decidi levantar acampamento e ir para o Canadá. E aí mais ou menos por acaso alguém me passou um anúncio para um posto de pós-doc. Estavam procurando alguém para fazer um pós-doc em Toronto com bilíngues, alguém que tivesse trabalhado com bilinguismo inglês-português, inglês-mandarim ou inglês-francês. O prazo já tinha expirado fazia tempo, mas eu liguei, e eles disseram: “Ah, graças a Deus! Não conseguimos ninguém para o posto! Você tem como pegar um avião, tipo agora mesmo?" Eu nunca tinha estado em Toronto, e nós que nos criamos em Québec temos grandes preconceitos contra Toronto.

Ruben Oliven: Você nasceu em Montreal, mas nunca tinha estado em Toronto?

Monica Heller: Eu nasci em Montreal.

Ruben Oliven: Mas nunca tinha estado em Toronto? 
Monica Heller: Não, porque Toronto não é um lugar a que se vai, se você é do Québec. Você vai para Londres, você vai para Paris, você vai para Nova Iorque, você para Los Angeles, talvez. Você vai para o México. Você não vai para Toronto. É um preconceito horrível. Toronto e Montreal eram cidades rivais desde o começo, e àquela altura, na verdade, foi exatamente o período em que Toronto estava tomando de Montreal o posto de centro financeiro do Canadá. Então ir para Toronto era entendido como traição. E, de fato, quando eu fui para esse pós-doc, - e eu pensei "bom, é um ano, se eu não gostar, eu posso ir embora" - e, sabe, na minha vida como jovem até então, eu já tinha morado nos Estados Unidos, tinha estado no México, tinha passado um semestre na França, eu tinha passado àquela altura um ano em Belgrado! $\mathrm{E}$ de repente eu me mudei para Toronto e todo o mundo em Montreal me perguntava "tem comida?", “dá para comer?", "como é a comida?”. Essa noção de que, sei lá, "eles não têm comida, eles só comem pão branco com", sei lá, "queijo branco" ou algo assim, era uma coisa cultural esnobe, realmente terrível. Bom, mas então eu consegui o pós-doc. O meu marido de então e eu fomos para lá para passar um ano. Ele ainda estava escrevendo a tese, e assim eu tenho uma dessas histórias que todo o mundo da minha geração que foi para Toronto naquela época conta: "Eu vim para ficar um ano e uma coisa levou a outra, e aqui estou eu." Às vezes é "eu conheci uma pessoa, me apaixonei", ou "meu marido arrumou emprego" ou "a minha mulher arrumou um emprego", ou então "tal coisa aconteceu, e eu então tive filhos".

Ruben Oliven: O seu marido também não era de Toronto?

Monica Heller: Meu marido era americano. A família dele não gostou.

\section{Ruben Oliven: Não o quê?}

Monica Heller: Não gostou. O pai dele era do serviço diplomático, então não era porque eles não estivessem acostumados, mas a noção de você escolher viver a sua vida sem ter uma base nos Estados Unidos era estranha. Os americanos têm ideias muito interessantes sobre o Canadá. Um outro jeito de me sustentar enquanto eu fazia pós-graduação foi dando aulas no Departamento de Francês. Eles estavam acostumados a ter gente da França; não era frequente terem 
professores do Canadá. Assim, as ideias que os meus alunos tinham... primeiro: "De onde você é na França?" "Bom, eu não sou da França." "De onde você é? $\mathrm{Ca}$ - Ca - Canadá?" Era muito, muito interessante. E eu fazia brincadeiras maldosas com as pessoas, especialmente na graduação. Eles diziam: "Ah, deve ser muito frio lá", e eu dizia: "Sim, é! É tão frio que a gente nem precisa de refrigerador; a gente só pega a carne e joga na rua na neve", e eles: "Mesmo, é frio assim!?!" Eu brincava com eles.

\section{Ruben Oliven: [risos]}

Monica Heller: Então, Toronto. Eu vim a descobrir todo um mundo de Canadá falante de francês, que o Québec tinha ideologicamente apagado completamente. "Opa, no fim a coisa é mais complicada", o que vem a ser o clássico antropológico.

\section{Ruben Oliven: Mmhm.}

Monica Heller: E era muito interessante. Daí fui contratada como pesquisadora e depois para fazer a gestão de um centro de pesquisa e consegui um cargo docente e... Isso na verdade era numa Faculdade de Educação; era uma instituição de pesquisa e ensino de pós-graduação que foi fundada para servir a toda a província de Ontário. Acontece que estava localizada em Toronto, com uma relação com a University of Toronto, porque os títulos de pós-graduação eram expedidos pela University of Toronto, mas nós estávamos diretamente subordinados ao Ministério da Educação. Era um lugar interessante para estar nesse sentido, porque realmente valorizava a mescla de ensino, pesquisa e o que então se chamava desenvolvimento comunitário, mas basicamente o que eles queriam dizer era trabalhar com pessoas que não eram acadêmicas, seja em que campo você estivesse fazendo coisas. Para nós, trabalhando com a comunidade francófona institucionalmente organizada, secretarias de educação de língua francesa, o millieu associatif politicamente mobilizado não sei como dizer isso em inglês, talvez em português seja - bom... de todo

2 Ver Heller (1999, 2011). 
modo, diferentes ONGs, diferentes maneiras de olhar, os funcionários públicos, todo o setor de políticas públicas, com o governo federal, sabe? Era exatamente a combinação de coisas... Sabe, era o emprego dos meus sonhos em muitos aspectos. Na University of Toronto, ainda havia uma separação, não tão extrema como agora, mas uma separação entre Linguística e Antropologia. E o Departamento de Antropologia era, e é, um departamento que tem os quatro campos, e havia colegas antropólogos da linguagem lá. Também tinha sociolinguistas com quem eu estava trabalhando. Bom, esse campo tem nomes diferentes, dependendo de onde você chega a ele. É Antropologia Linguística em um certo canto da Antropologia na América do Norte, é Sociolinguística em boa parte do resto do mundo, é Linguística Aplicada no Brasil e na Grã-Bretanha, talvez em outros lugares também. Mais uma vez, estamos no campo dos cruzamentos de fronteiras, do que é difuso, e assim eu tenho um pé na Antropologia e o outro pé nesse Instituto. Em termos de buscar espaços e colegas, bom, eu tinha sido formada nos Estados Unidos, trabalhando no Canadá, em um campo que tinha uma espécie de versão em francês no Canadá, mas não tanto na Antropologia. A essa altura, Gillian Sankoff tinha se mudado do Canadá para os Estados Unidos. Ela se divorciou de David Sankoff e se casou com Erving Goffman, um sociólogo muito, muito conhecido, e daí ele morreu, e então ela se casou com William Labov, o famoso sociolinguista, e eles ainda estão juntos. Então ela se mudou para a Filadélfia, e as pessoas que se sucederam a ela em Antropologia Linguística na Université de Montréal à época estavam fazendo, eu acho, naquela época, mais o que eu chamaria de Linguística descritiva boasiana, portanto, não tanto a minha praia... Nos aproximamos mais recentemente, nossos interesses convergiram mais nos últimos tempos, e outras pessoas foram contratadas desde então em outras universidades. Enfim, não havia um campo propriamente dito. Não havia um espaço institucional para aquilo. Então os espaços que eu encontrei foram a Antropologia Linguística no mundo de língua inglesa, a Sociolinguística de língua francesa, incluindo um grupo de pessoas muito ativas na França que compartilhavam comigo o interesse por desigualdade social e trabalho, os espaços de trabalho como uma área importante de investigação. E aí também havia gente na Grã-Bretanha interessada em imigração e multilinguismo. Assim eu de certo modo moldei esses espaços encontrados, nem sempre com facilidade. Eu estava falando disso antes para vocês dois, eu acho, sobre a experiência 
que eu tive da primeira vez - ou seja há o problema da publicação, a que a gente pode retomar mais adiante - a primeira vez que eu mandei um artigo com uma colega minha em Toronto que era originalmente da França para um periódico que existe em francês no campo, publicado em Paris, Langage et Societé, e era isso. Então a gente mandou o artigo, e, na resposta do professor de Sociolinguística que era o editor, ele nos disse: "É muito interessante, mas realmente muito mal escrito. $O$ francês canadense de vocês é terrível, dá para ver que está infectado pelo inglês. Vocês têm essa longa seção de metodologia. Não precisamos dessa seção de metodologia. Para quê, isso? Quem se importa?" Então respondemos, dizendo: "Monsieur Achard, cher collègue, como sociolinguista, o senhor provavelmente sabe que há uma coisa chamada variação. Nem todo o mundo usa a linguagem do mesmo modo, por razões sociais e culturais, e nós temos uma relação complicada de colonialismo entre o Canadá e a França, que, o senhor provavelmente vai concordar, nós não devemos simplesmente aceitar..." Enfim, ele afinal voltou atrás. Nós também explicamos a ele por que a seção de metodologia, que, da perspectiva da América do Norte, seções de metodologia são importantes. Afinal publicamos, mas tivemos que brigar, tivemos que fazer um arrazoado. Então, desde o início da minha carreira, eu estive ocupada fazendo arrazoados todo o tempo, fazendo arrazoados para ganhar financiamentos, fazendo arrazoados para explicar para o pessoal de linguagem o que é etnografia... etnógrafos não lidavam com linguagem; o pessoal de linguagem não fazia etnografia, então eu tinha que explicar o que era aquilo. Então houve um período, sabe, em que eu fiquei me perguntando.. sabe, isso é meio tedioso, as outras pessoas não têm que fazer isso, mas aí me dei conta de que eu estava de fato aprendendo muito com o exercício de ter que fazer o arrazoado a toda hora. Então eu acho que, no fim, foi bom para mim, para a minha docência, para a minha pesquisa, bom para a minha capacidade de trabalhar com a mídia. E, assim, por um tempo eu ia a congressos na França, ia a congressos em francês no Canadá, não tanto congressos em inglês no Canadá. Eu estava com um pouco de dificuldade de fazer conexões ali por conta de eles não quererem muito tratar de francês a não ser que fosse francês como segunda língua. Então a maior parte do trabalho sobre bilinguismo no Canadá inglês era sobre como ajudar as crianças anglo a aprender francês, o que não era a minha praia, e isso normalmente de uma perspectiva meio técnica, muito pouco crítico-etnográfica, nada de crítico-etnográfico. 
Então eu ia aos Estados Unidos para a Associação Americana de Antropologia, onde muitas vezes eu apresentava meu trabalho, e as pessoas diziam: "Ahn, isso é tipo assim como o espanhol nos Estados Unidos?” E eu dizia: “Não, não é." E aí, lá pelas tantas, eu fiquei farta e frustrada, mas depois me dei conta de que sempre eu aprendia alguma coisa. Dali eu sempre voltava com alguma ideia que de outro modo nunca teria. Então falei: "Volta, mas, se tiver frustrada, então abre a boca, Monica!" Sabe, não se pode ter tudo. Então comecei a abrir a boca. E daí fui chamada por uma colega, uma antropóloga linguista, que hoje está na University of Chicago, Susan Gal, para ajudar com a administração da parte da Associação Americana de Antropologia que faz Antropologia Linguística, e assim fiz a secretaria. Por meio disso, uma vez que você se envolve em prestação de serviço nessa associação, e você faz isso de modo minimamente decente, sabe, o seu nome está numa lista.

Ruben Oliven: Muito bem.

Monica Heller: Certo? Mas eu gostei daquilo, porque, diferente de reuniões de departamento, em que em geral as pessoas estão brigando sobre perfis de vagas, ou que estudante deve ganhar o auxílio, e em geral não é muito agradável, ali era só gente que queria estar ali. E porque era um espaço antropológico de quatro campos, eu comecei a me sentir como se estivesse numa confeitaria, ou numa loja de guloseimas. Eu podia ir e ver o que as outras pessoas estavam fazendo, e, se me interessasse, eu podia explorar isso de um modo muito eficiente, sabe, em cinco dias. E conhecer esses colegas pessoalmente, por conta da prestação de serviço, e descobrir coisas por intermédio deles, uma vez que tínhamos uma relação pessoal. E aí o pessoal da Antropologia Linguística solicitou que eu concorresse para atuar no conselho executivo da associação como um todo, e eu fiz isso, e por conta disso pude, sabe? - foi incrivelmente esclarecedor. Aprendi muito sobre o campo, não só nos Estados Unidos, mas aprendi muito sobre o campo em âmbito global. E havia um espaço onde a gente podia falar sobre a política do campo, a política conectada com os diferentes modos de fazer Antropologia. Portanto, muito reflexivo. Realmente interessante. Eu realmente gostei. E, para meu aperto, a presidente que estava assumindo me pediu... perdão, quando eu saí do conselho executivo, ela me pediu para organizar o congresso de 2010 em 
Nova Orleães, que eu sabia que ia achar interessante, porque eu sabia que a Luisiana era interessante, e, sei lá, eu gosto de organizar coisas. Então fiz isso. E aí fui instada a me candidatar, a concordar em ser indicada para concorrer a presidente para a gestão seguinte. Então essa foi a hora da verdade, em que eu pensei "bom, vou ter que dizer o que eu penso", sobre, sabe, o problema real de a Antropologia dos Estados Unidos dominar o universo, o problema de o inglês ser "a" língua importante para publicação, de modo que - e eu não estava sozinha em achar isso problemático, certo?

\section{Ruben Oliven: Mmhm.}

Monica Heller: Mas eu sentia que, claro, podíamos bater nessa porta pelo lado de fora, mas, quando você está no centro de um espaço de poder, tem muito que podemos fazer, e era isso que eu queria fazer se fosse eleita presidente. Porque calculei que, se as pessoas não quisessem isso, elas não iam votar em mim. E isso seria um recado claro.

\section{Ruben Oliven: Mmhm.}

Monica Heller: E então eu fui eleita. Então eu tinha esses quatro anos, dois como vice-presidente, presidente eleita, dois como presidente, que foi como eu tive a oportunidade de conhecer você, Ruben. Na época em que o Conselho Mundial de Associações de Antropologia estava se constituindo e a então União Internacional das Ciências Antropológicas e Etnológicas estava sendo revitalizada, como canadense, era um bom momento para ser - quer dizer, era um bom momento para ter uma canadense como presidente da Associação Americana de Antropologia. E, então, sabe aquilo que eu disse que eu queria fazer? Eu tive a oportunidade de trabalhar especialmente com as grandes associações coirmãs, vocês aqui no Brasil, a japonesa e as europeias. Fizemos uma série de coisas, por exemplo, fizemos um webinar com os... eram os europeus, os brasileiros, os canadenses e americanos, fizemos um webinar sobre o problema do inglês e o multilinguismo na produção de conhecimento antropológico. Fizemos um monte de coisas. A outra iniciativa importante foi um dossiê que eu recebi para os dois anos da minha gestão na presidência, o desejo por parte de uma parcela significativa dos associados de discutir o movimento de 
boicote e sanções disciplinares contra Israel. ${ }^{3}$ Isso tomou muito do meu tempo, e também foi extremamente formativo para mim. Eu me sinto bastante bem a respeito de como as coisas correram. Eu não acho que poderia ter feito melhor, vamos dizer assim. Não tenho arrependimentos em relação ao modo como lidei com a questão. Não fico acordada de noite pensando "eu devia ter feito isso, eu devia ter feito aquilo".

Ruben Oliven: Mmhm.

Monica Heller: Talvez não tenha sido bom, talvez não tenha sido certo, mas eu não podia ter feito nada mais do que fiz. E, claro, quando você é ex-presidente, a AAA nunca deixa você partir, então tem sempre isso, tem sempre isso acontecendo. Mas também me deu a oportunidade de retornar ao envolvimento com os meus colegas canadenses e com colegas na Europa, e por conta disso tenho feito muito trabalho colaborativo por todo o Canadá. E, sobre o que não falei nada ainda é sobre pesquisa, mas vocês vão ter que me perguntar a esse respeito separadamente, porque estou cansada dessa história.

\section{Monica Heller/Ruben Oliven/Pedro Garcez: [risos]}

Ruben Oliven: Algo muito interessante no seu trabalho é quando você trata da questão de a linguagem dizer respeito a mais do que uma estrutura que fornece ferramentas para fazer sentido do mundo e que você deve ver a relação entre a linguagem e a produção de diferença social e da desigualdade social. Você acha que essas duas coisas são incompatíveis? Ou há um modo de reuni-las? E qual é o papel da ideologia nesse processo? Só para tornar as coisas mais complicadas...

3 Em assembleia geral em novembro de 2015, a Associação Americana de Antropologia aprovou uma resolução para colocar em votação, em abril de 2016, proposta de boicote da entidade às instituições acadêmicas israelenses (ver American Anthropological Association, 2015). Argumentos contra e a favor estão listados em American Anthropological Association (2016a, 2016b). Com participação de 51\% dos eleitores habilitados, a proposta foi rejeitada por 2423 votos contrários, uma margem pequena, já que 2384 votos foram pela aprovação (ver American Anthropological Association, 2016c). 
Monica Heller: Bom, vou ter que voltar para ideologia mais tarde.

\section{Ruben Oliven: OK.}

Monica Heller: Uma sociolinguista variacionista me fez uma pergunta parecida durante o curso que eu dei esta semana aqui, vindo do outro lado da questão. Bom, eu tive que me ocupar durante muito tempo - eu não sabia dizer, até o trabalho como estudante de pós-graduação - tentando descobrir: "No que eu acredito?" Porque nós somos treinados absolutamente, mesmo como linguistas antropólogos, para acreditar que língua é um objeto estruturado, integralmente delimitado, que pode estar localizado no cérebro, talvez na mente, algo cognitivo, não temos certeza. Mas se situa em relação à organização social, de algum modo. E a tarefa é descobrir essas maneiras. E assim na tradição de Franz Boas, que é dominante na América do Norte, as coisas estão loteadas. Sim, veio da noção de que tudo isso faz parte da cultura, são todas dimensões da vida social, mas são divididas. Então você trabalha sobre linguagem, ou você trabalha sobre o corpo, você trabalha sobre práticas religiosas. Mas, até onde eu posso perceber - você provavelmente sabe mais sobre isso do que eu -, isso foi montado como abordagens distintas meio que desde o começo. Então ninguém formulou a pergunta sobre o que - sabe... Talvez, talvez, fazendo perguntas sobre o que há de comum entre as estruturas... e toda a virada lévi-straussiana, eu acho que em parte foi sobre isso... ao mesmo tempo que temos a virada estruturalista chomskiana... a nossa tarefa é encontrar as estruturas subjacentes universais de tudo, e, se estivermos certos, então todas vão se sobrepor, as estruturas linguísticas vão se mapear sobre as estruturas sociais e assim por diante. Ao que parece isso não ocorre, ou então não descobrimos como. De todo modo, essa não era a questão que me interessava.

Ruben Oliven: Mmhm.

Monica Heller: Mas também não parecia funcionar. Então isso era um problema para mim. E, empiricista pouco refinada que eu sempre fui, a minha questão sempre foi "olha, isso tudo está acontecendo; eu tenho que ser capaz de explicar!". E estrutura linguística não explica, de todo. Ainda assim, consigo ver modos como a estruturação da linguagem, como ela está estruturada, se torna 
disponível, como um recurso comunicativo, para fazer coisas interacionalmente, e a estruturação da interação se torna disponível para negociar divisas sociais, negociar diferença social, notadamente, quem consegue acesso a quê. E então podem ser tipos de coisas práticas, como uma resposta do motorista de ônibus, ou a marcação de consulta com o médico. Quero dizer, isso era a vida que eu estava vivendo. Era isso que estava em jogo na vida cotidiana na policlínica do Hospital Victoria. E aí há coisas maiores em jogo, como o acesso de uma geração à educação e a empregos. Então, eu conseguia ver os modos como... desculpa! Ao mesmo tempo, você tem todo esse papo de "nós vamos mudar o mundo fazendo uma política linguística pública”. Ahn? Sabe, como? E é isto que eu aprendi com John Gumperz, que foi meu mentor, que realmente se focava na interação social como o lugar onde a coisa social acontece: que foi apreciar esse lócus da interação social, mas como algo com uma história, e algo com uma estrutura. E assim a pergunta passou a ser qual é a história - qual é o passado e qual é o futuro, e o que está se passando ao mesmo tempo, e o que a estrutura tem a ver com isso? E nisso eu fui influenciada por algumas pessoas importantes. Uma foi Aaron Cicourel, que é um sociólogo etnometodólogo também interessado no processo interacional institucional. Outra foi Anthony Giddens, um sociólogo britânico. Então o problema da agentividade-estrutura era a questão. Indo adiante rapidamente, passei a crer que a estrutura é algo que você faz, com os recursos simbólicos e materiais que herdamos, porque eles não caem do céu, a partir dos quais fazemos sentido. E a produção de sentidos só poderia acontecer no aqui-e-agora, mas é um aqui-e-agora que tem uma história e está conectado com outro aqui-e-agora em alguma outra temporalidade ou alguma outra espacialidade. Assim, a chave do jogo, se você quiser, é elucidar as conexões, elucidar as sequências, elucidar o que está conectado com quê, e como. E notadamente, então, quais são as consequências, digamos, para o que fazemos agora em termos de possibilidade, para nós três, ou para esses dois caras, ou para pessoas que não se encontraram, ainda? Ou seja, sempre há coisas que importam. E isso circula. Produção e circulação só acontecem em algum lugar que é observável de algum modo. Então eu sou, sabe, realmente empiricista nesse aspecto. Aqui é onde eu realmente me apoio em Pierre Bourdieu e na noção de valor, e de mercado. Em particular naquele momento, eu estava fazendo pesquisa em cenários educacionais na escolarização de uma minoria linguística, um campo realmente importante na mobilização política das minorias linguísticas, e ele, claro, com 
Jean-Claude Passeron, trabalhou muito sobre escolas como agências de reprodução social, e estava vendo isso diante dos meus olhos e no terreno da linguagem. No terreno da linguagem, mas, você também podia ver aquilo, pela manipulação de recursos comunicativos na interação social, dia após dia, semana após semana, ano após ano, e de maneiras que claramente se conectavam com os funcionamentos das coisas acontecendo em outros espaços institucionais, não apenas na educação. Assim, passei a ver a linguagem como prática social, mas, tal como a prática social é estruturada, também os recursos comunicativos que são parte dessa prática social. Uma das coisas que têm se passado nos últimos 40 anos ou algo assim - bom, quando eu comecei como estudante de pós-graduação, as pessoas estavam muito interessadas em todo tipo de prática comunicativa - gesto, direcionamento de olhar, corpo - e isso meio que ficou pelo caminho, por alguma razão, sabe, que eu poderia tentar explicar. Mas nos 1980 e 1990, ao menos nos mundos em que eu estava ativa, isso meio que saiu, mas agora voltou. Então esse reconhecimento de que precisamos falar de todo tipo de prática comunicativa e de todo tipo de canal de comunicação, e dos modos em que a estruturação dos recursos comunicativos - que vamos chamar de língua para os propósitos da nossa discussão aqui hoje, mas na qual não acredito, certo?, quer dizer, a noção de línguas - e aqui vou falar de ideologia - é uma estruturação ideológica. Então, o nosso conceito dessas coisas como sendo íntegras e delimitadas e em relação uma a outra, mas não em relação uma da outra, para mim resulta da relação complicada entre o colonialismo e o Estado-nação. Portanto, culturas e grupos e línguas foram moldados a marretadas para permitir a criação e o gerenciamento de diferença social e da desigualdade social, para dizer de um modo meio grosseiro, legitimadas ideologicamente por toda sorte de histórias interessantes que nós contamos sobre nós mesmos e uns sobre os outros. Assim temos ideologias de linguagem e de culturas, que estão encaixadas em ideologias legitimadoras. E essas têm se tornado realmente o cerne daquilo pelo qual eu passei a me interessar em compreender e sobre o que trabalhar, de maneira que, sabe, me encontro limitada, desconfortavelmente, de ter que falar sobre língua quando o que eu realmente acredito, e isso vem de - para mim, a imagem que funcionou foi, do trabalho de Voloshinov e Bakhtin, ou Bakhtin Voloshinov, provavelmente Voloshinov - da ideia de que os recursos comunicativos, como quaisquer outros recursos, circulam. Como os corpos circulam. $\mathrm{E}$ assim, como falantes, somos posicionados de maneiras tais que temos 
acesso, acesso mais fácil, a certos tipos de recursos, assim como agora eu tenho acesso fácil a água e um caderno de notas, e coisas saindo da minha boca que a gente aprendeu a chamar de inglês, francês, e estou aprendendo um pouquinho de português com vocês. E assim eu posso fazer isso; não posso me valer de alguma coisa que podemos chamar de japonês. Estou realmente longe disso. Se eu quisesse me valer disso agora, teria que fazer algum esforço para fazer isso. Se eu quisesse alguma coisa para comer, eu teria que parar a interação e pedir para vocês. Assim, conforme eu estou posicionada socialmente, que é uma questão completamente ideológica, também me posiciona com respeito aos recursos comunicativos, os quais, junto com os meus interlocutores, chegamos a algum tipo de arranjo sobre como estruturar, de modo que possamos falar uns com os outros, ou escrever uns para os outros, ou seja qual for a tecnologia, ou abanamos uns para os outros, inclusive instruções corporais, que vamos usar. E assim não está aqui dentro ou lá fora; passa por uma variedade de meios, que atuam como limitadores. Não é toda e qualquer coisa que eu posso fazer com o meu aparato vocal, mas há toda uma amplitude de coisas que eu posso fazer com o meu aparato vocal. E eu posso organizar isso em partes de modos muito diferentes, embora você e eu vamos ter que concordar que vamos organizar isso em partes, de certos modos, porque vamos usar os recursos dessa maneira. E há muito, muito trabalho sobre mudanças nos sistemas de vogais ou de consoantes das diferentes línguas, porque o espaço das vogais ou das consoantes podem ser espaços meio soltos, conforme for o caso. Você pode mover, para cima e para baixo, para frente e para trás. Então sempre temos espaço de manobra, sempre temos um espaço para mexer as coisas, para fazer sentido de maneiras que -, algumas podem ser icônicas, é possível, "ik" pode, sabe, ter algum tipo de significado icônico em comparação com “ã-". É uma hipótese. Tem sido uma hipótese favorita de muita gente. Talvez. Então, acho que podemos entender muito sobre o processo social. Na verdade eu não sei como nós vamos entender muita coisa do processo social sem entendermos como as pessoas se comunicam umas com as outras.

Ruben Oliven: Mmhm.

Monica Heller: Podemos entender obviamente os artefatos que eles produzem, mas eles os fizeram. É ação. Alguém teve que fazê-lo, em interação, com 
recursos que atualmente em geral concordamos em não chamar de humanos, mas isso está mudando também. Então, sim, tenho estado de certo modo indo contra esse conceito, essa ideologia de língua como objeto íntegro e delimitado, distinto de cultura e sociedade. Penso que é tudo uma única coisa, e é só uma questão de qual é o ponto de entrada onde está o seu interesse ou que por acaso está disponível para você.

Ruben Oliven: O seu trabalho enfatiza muito fortemente o papel do Estado-nação e as línguas, sim?

\section{Monica Heller: Sim.}

Ruben Oliven: OK, e agora você se dirigindo, ou já se dirigiu para a questão da linguagem no arcabouço da globalização ou do capitalismo tardio. Você poderia falar um pouquinho sobre isso?

Monica Heller: Sim, bom, isso sou eu seguindo onde aponta o meu nariz, assistindo ao que está se passando à minha volta. As experiências de infância que eu estava contando para vocês há pouco foram um momento de desenvolvimento do nacionalismo québécois. E assim eu pude ver tentativas por parte de alguns atores sociais de construir algo que eles queriam chamar de um Estado-nação, e outras pessoas resistindo a isso. Então, no espaço canadense, se o Québec se constrói como um Estado francófono - porque um dos emblemas do Estado-nação é uma língua-padrão e espaços monolíngues -, antes de isso acontecer, havia toda sorte de gente que se entendia franco-alguma coisa, mas não québécois, então isso era um problema para essas pessoas. ${ }^{4}$ Uma das respostas seria os québécois dizerem para eles: "Mudem-se para cá. Afinal, vocês vão desaparecer de qualquer jeito mesmo. Então aproveitem e se mudem para cá." E essas outras pessoas diriam: "Ih, sabe, a gente não tem como fazer esse Estado-nação territorializado." O que a ordem mundial global consagra como a unidade política de organização - a ONU é uma organização de Estados nacionais soberanos, e isso é para ser a meta para todo o mundo e tudo - é que o

4 Refere-se à população francófona em outras províncias canadenses que não o Québec. Ver Heller et al. (2016). 
mundo devia estar loteado em nichos-chave bem organizados. E quando eu me encontrei em Toronto, é claro, o que estava diante de mim era a bagunça que sobrou disso, do que se tentou fazer. Tinha sobrado bagunça dentro do Québec também. A população indígena, o que hoje a gente chama de nações originárias e inuit, e também várias outras gentes de outras origens, foram chamadas a integrar o espaço francófono, mas com desconfortos, e isso ainda é um problema hoje, isto é, se você pode realmente se transformar num québécois francófono, porque a coisa nacional tem tanto uma dimensão liberal-democrática racional-iluminista - qualquer um pode ser um cidadão, aprenda esta língua racional e racionalmente você será um cidadão racional -, quanto uma dimensão nacional romântica, de fazer parte de uma nação orgânica com raízes no solo. Então, como você usa isso para fazer aquilo parece ser mais das coisas que não funcionam. Tem sido um problema, e nós temos andado em círculos em torno disso pelos últimos 50 anos, e segue sendo um problema que temos. E aí tem essa outra bagunça, não no Québec, que é: "Espera um pouco, nós somos essa coisinha francófona! Como é que vocês ousam dizer que nós não somos?" E assim eu estou seguindo isso tudo e como eles lidam com esse problema e as contradições que surgem e os modos como as pessoas tentam neutralizar essas contradições e então como outras ideologias surgem, como, talvez, mais bem situadas para as realidades que estamos enfrentando, e talvez essa coisinha de Estado-nação monolíngue esteja demasiadamente em contradição com essa coisinha democrática, de modo que a gente não consiga fazer essas coisas se encaixarem e, portanto, temos que repensar a coisa toda. E assim encontramos gente resistindo a isso. Ao mesmo tempo, então, isso é onde - sabe, eu nunca era, eu nunca lia as páginas de negócios dos jornais quando era jovem, até eu começar a descobrir que, na verdade, no fim a economia é realmente importante. ${ }^{5} \mathrm{O}$ terreno em que as pessoas com quem estou trabalhando de fato estão lutando é de fato o acesso ao controle sobre a riqueza, sobre a entrada na coisa-Canadá-o-país-capitalista. Então, quem controla os recursos? No que se baseia a economia canadense? Assim tive que começar a tentar entender a relação entre a indústria madeireira e as brigas sobre o bilinguismo. Há uma conexão direta aí, mas eu tive que deslindar isso, porque as pessoas de linguagem

5 Ver, por exemplo, Heller (2010, 2011) e Heller e Duchêne (2012, 2016). 
normalmente não tratam da indústria madeireira e as pessoas da indústria madeireira normalmente não tratam de linguagem. Eles só sabem que, se você precisa de gente no norte de Ontário para serrar madeira, as pessoas que provavelmente você vai conseguir são franco-canadenses e talvez gente da ilha de Cabo Bretão na Nova Escócia. Essas são os nossos excedentes laborais.

Ruben Oliven: Mmhm.

Monica Heller: E eles não fazem perguntas a respeito disso. E quando essa gente chega nos acampamentos das serrarias, a questão de como eles vão se comunicar também não surge. E o mesmo acontece hoje na mineração de petróleo no norte de Alberta. Então você pergunta para os falantes de francês o que é que acontece, e eles dizem: "Bem, primeiro eu tenho que me concentrar muito, muito, muito, muito para entender, sabe, esse inglês." "E ninguém tenta-" "Nã, nã, nã." Isto é, os falantes de inglês falam inglês e os falantes de francês têm que aprender. Outra forma de dominação simbólica que reproduz...

Ruben Oliven: Mmhm.

Monica Heller: O que também veio a ser como eu passei a entender "anglo" e "franco", e "Newfie" e "Cape-Bretonnie" como essencialmente rótulos de etnoclasse.

Ruben Oliven: Mmhm.

Monica Heller: E as diferenças linguísticas e culturais como modos de a gente legitimar a manutenção de uma certa população excedente como repositórios laborais excedentes e em nichos laborais específicos, que não é algo que as políticas linguísticas canadenses de fato jamais tocam. Portanto, o que estava acontecendo, então, ao mesmo tempo, é que a base, de certo modo a maneira como as coisas estavam organizadas, os movimentos estado-nacionais québécois para tomar o poder político e o controle do setor privado da economia do Québec num espaço monolíngue não podiam funcionar, porque essa não é uma economia autossuficiente. De modo a fazer dinheiro a partir do que você tem, você tem que lidar com gente que não fala francês. Assim, se você quiser fazer uma 
grande represa para produzir energia hidroelétrica no norte do Québec, quem é que vai consumir isso? Não só os québécois. Você pode nacionalizar a companhia hidroelétrica e usar isso para criar espaços de mobilidade social para engenheiros francófonos tecnicamente recém-treinados, mas em algum momento alguém vai ter que lidar com o resto do mundo. E rapidamente, no final dos 1980 e início dos 1990, há toda uma restruturação que nos afeta, em que as maneiras em que os "bastiões tradicionais" - como a gente chama - da francesidade no Canadá não conseguem se reproduzir. E aí eu olho e me dou conta "ih, alguma coisa está acontecendo aqui", que na realidade se conecta com as discussões que as pessoas estão tendo sobre Reagan e Thatcher. Tudo isso está conectado. Então, sabe, observo que a indústria da pesca de bacalhau no norte do Atlântico, do lado canadense, fecha, como atividade básica de manutenção, por conta da pesca excessiva. Então tem todas essas coisas de recursos primários. Ou então se torna muito caro retirar esse mineral do solo; é mais barato retirar do solo na Bolívia. E aí se você quiser trabalhar em mineração você tem que ir para a Bolívia, ou então encontrar outra atividade para se sustentar. E assim comecei a observar o que estava se alterando e como as pessoas estavam se reorganizando de modos que imediatamente se conectam a redes globalizadas. Isso também me fez me dar conta de que, claro, sempre estivemos em redes globalizadas. Sabe, a história que nos contam quando nos mostram - "Veja, aqui está o mapa do Québec, aqui está o mapa do Canadá, aqui estão essas fronteiras..." -, todo esse lugar só existe em função do imperialismo europeu! Outro livro importante para mim foi Europe and the people without history, de Eric Wolf. ${ }^{6}$

\section{Ruben Oliven: Mmhm.}

Monica Heller: Sabe, o capítulo sobre o comércio de peles abriu os meus olhos. Bom, então isso quer dizer que a gente precisa repensar toda essa coisa de globalização e tentar entender, para as coisas que me interessam, como isso reconfigura, nos diferentes momentos de conexões imperiais, internacionais, globais, os rótulos que são de certa maneira emblemas para se falar dos diversos modos em que as circulações planetárias estão organizadas em termos de relações de

6 Ver Wolf (2009). 
poder e em termos das diferenças linguísticas e culturais e sociais que fazem com que isso tudo faça sentido. Sabe, a Metrópole imperial, a Metrópole colonial em oposição às Américas incivilizadas...

\section{Ruben Oliven: Mmhm.}

Monica Heller: ... o Canadá surgindo das trevas como Estado-nação saindo do Império Britânico. O que é preciso para fazer isso? Por que fazer isso? Por que seria interessante fazer isso? O Québec dizendo: "Não queremos brincar desse Estado-nação; queremos outro Estado-nação." E tantas outras pessoas a certa altura dizendo: "Essa coisa toda de Estado-nação não está mais funcionando para nós", e produzindo formas de expressão, muitas vezes na cultura pop na verdade, primeiro de certo modo desestabilizando isso e depois, eu diria...7 Então, agora tenho estado seguindo as pessoas fazendo duas coisas. Uma é a reação fortíssima: "Não, vocês não vão desestabilizar isso! Nós fizemos isso, funcionou para nós. Vocês não vão nos tirar", que eu entendo ser uma reação. Não consigo entender de nenhum outro modo, porque ao mesmo tempo estou vendo essas outras coisas se passando ao mesmo tempo.

\section{Ruben Oliven: Mmhm.}

Monica Heller: Que vem a ser "isso é problemático", "isso é estrangulador", "isso não é justo" e, portanto, "a gente quer imaginar alguma outra coisa".

\section{Ruben Oliven: Mmhm.}

Monica Heller: E assim só estou tentando seguir, só estou tentando entender o que está acontecendo. Tudo isso está em relação. Isso está claro para mim. E assim a alteração no meu trabalho tem sido apenas - é possível entender de duas maneiras: uma é que a Monica vai entendendo melhor as coisas à medida que vai ficando mais velha, e a outra é que as coisas estão mudando, e, portanto, você tem que encontrar uma explicação.

7 Ver Heller (2011). 
Ruben Oliven: Como você desenvolve pesquisa sobre isso tudo?

Monica Heller: Certo, sim, então, somos todos de certo modo treinados para sermos etnógrafos solitários, mas, na realidade, durante a maior parte da minha vida, eu trabalhei em equipes. Eu era a etnógrafa solitária na clínica ambulatorial, somente porque as outras senhoras que trabalhavam comigo, elas eram adoráveis, mas estavam fazendo o trabalho delas, certo? Elas queriam se certificar de que a Monica ia tirar uma nota boa, e por isso me ajudavam, porque eu era uma estudante àquela altura. Então em certo sentido eu poderia afirmar que eu era a única formulando perguntas, que não eram desinteressantes para as minhas colegas de trabalho - nada disso - porque elas estavam vivenciando aquilo também. $\mathrm{E}$ a gente de fato conversava sobre tudo, e eu aprendi muito a partir disso, mas afinal era eu quem tinha que apurar aquilo tudo e escrever uma dissertação de mestrado. Já para o doutorado, o que acontecia é que, 1976, havia um governo independentista eleito na província do Québec e preparação de legislação linguística. E houve legislação linguística antes - com efeito, no início dos anos 1960, o governo do Québec criou uma agência de legislação linguística no bojo do que eu falei para vocês antes, com o propósito de facilitar as mudanças ou as políticas linguísticas públicas que o governo queria instituir, e tinha pesquisa sobre isso, e eu fiz um estágio lá por seis meses quando era estudante de pós-graduação. E uma das pesquisadoras com quem eu estava trabalhando estava aplicando questionários. Eles mandavam questionários para grandes empresas, que eram as que eles tinham como alvo principal para a "francisation", como eles chamavam, para ver o que os trabalhadores estavam falando. Ela não tinha carro e me pediu para pegar o carro dos meus pais emprestado para levá-la até essa grande fábrica de automóveis na região de Montreal para recolher os questionários, porque eram caixas de questionários. E assim, eu estava levando Dénise até St. Thérèse... e na volta: "Sabe, se eu fosse um trabalhador nessa empresa e eu recebesse um questionário como esse, eu ia simplesmente preencher francês, francês, francês, francês, francês... francês, francês, francês... francês, francês, francês, francês... todo o tempo, porque eu sei que é isso que vocês querem. Não sei se um questionário, sabe..." Eu já tinha sido envenenada pela Etnografia, e a Sociolinguística Interacional, então, isso era a crítica dos questionários. E então ela me diz: "Você é tão esperta, sabe? Então como é que você faria isso?" E aí eu ali, dirigindo o carro, inventei um estudo etnográfico. Ela então diz: "OK, nós 
temos um programa de financiamento. Você devia inscrever um pedido de apoio para fazer essa pesquisa." Ai, bem... Ela foi maravilhosa. Ela me ajudou. Mas eles também disseram: "Sabe, a gente não acha que você consegue fazer isso sozinha. A empresa é muito grande. Também é uma fábrica industrial... uma mulher de vinte e poucos anos sozinha, ih... Você sozinha, por um ano e meio, ou - é, você precisa de uma equipe. Então você vai prever no orçamento que vai contratar outros estudantes de pós-graduação para trabalhar com você." Para encurtar a história, ganhei o financiamento e contratei três outros estudantes de pós-graduação. Então eu já estava - na minha primeira experiência de trabalho de campo de fôlego, eu já estava trabalhando em equipe. E daí na minha primeira pesquisa em Ontário, eu, sim, fiz sozinha. Passei seis meses em uma escola primária. ${ }^{8}$ E daí, com o passar dos anos, em parte porque eu estava em um centro de pesquisa, havia muitas solicitações para certas tarefas, e um dos meus colegas, Raymond Mougeon, era um variacionista, mas ele tinha uma noção - e estávamos mais ou menos no mesmo terreno, mas com abordagens diferentes. E então ele pensou: "Mmm, isto pode ser interessante, sabe, reunir os dados que a Monica tem e os dados que eu tenho, então que tal se a gente escrevesse alguma coisa juntos?" E eu disse: "Claro, quero tentar fazer isso." E escrevemos coisas juntos. Assim, houve sempre muito trabalho em equipe no centro de pesquisa por conta do tipo de pressões, por assim dizer, políticas, sociopolíticas, políticas para se fazer certos trabalhos de certos modos, e num certo cronograma. E assim me acostumei a isso, e daí, conforme comecei a - se vocês lembram, a minha coisa é começar aqui e seguir as coisas. E você começa a seguir por aqui, e você começa a seguir aqui e você começa a seguir aqui e por ali. A minha colega Sari Pietikäinen usa o conceito de rizoma de Deleuze e Guattari para descrever isso; para mim é mais uma ideia de teia. Então as coisas vão em diferentes direções. Eu nunca pensei em etnografia como algo holístico. Eu seria alérgica a isso. Acho que tudo está conectado em muitos tipos de maneiras. Eu acho que nós construímos divisas, e, portanto, eu poderia justificar o trabalho somente na escola em função de você ter divisas territoriais - isto é propriedade escolar - e divisas temporais - trim, trim, o sino toca; agora a escola começa. E eu podia ver as crianças brincando com essas divisas. Ainda assim, obviamente, para entender 
o que realmente estava se passando, eu precisava entender as trajetórias das crianças e as trajetórias dos currículos e as trajetórias de toda a instituição da escola... porque houve uma época em que era ilegal usar o francês como língua de instrução. Portanto, as coisas seguem em diferentes direções, e você pode fazer menos, sozinho, mas é muito interessante trabalhar com outras pessoas. $E$ tem a questão do posicionamento social outra vez: na fábrica, foi de fato um problema saber onde colocar a mim e à outra mulher que estava na equipe, porque a maior parte do espaço era masculino. Por exemplo, para acompanhar os caras que faziam as rotas de entregas nos caminhões, sim, eu podia fazer isso, mas todo o mundo ficava muito mais à vontade se fosse um cara a fazer isso. Portanto, há coisas generificadas, e tem também coisas de idade. Se você está trabalhando numa escola... quando eu comecei, eu era jovem o suficiente para poder passar como uma estudante mais velha de ensino médio; anos depois, é só "madame, madame, madame". Você é ou mãe, ou professora, ou algo assim, e isso é uma relação muito diferente com as crianças. Mas trabalhar com estudantes de pós-graduação ajuda com isso. E há também aspectos sociais. Assim, os alunos que são os mais marginais na escola, os fumantes, os que, sabe, chegam para a aula atrasados, ficam lá no fundo na área de fumantes, coisas desse tipo. Eles sobrevivem por conta de uma solidariedade muito apertada. Se você quer entender a ecologia da escola, você não pode abandoná-los depois de estabelecer uma relação de confiança com eles. Você não pode abandoná-los. Então ou você - e isso é uma das razões por que, eu acho, Penny Eckert acabou trabalhando tanto com os burnouts. ${ }^{9}$ Assim, ter homens e mulheres, negros e brancos, gente mais velha e gente mais nova... E aí começamos a trabalhar com colegas de outras partes do mundo, em particular alguns alemães que estavam interessados no Canadá, e alguns colegas acadianos ${ }^{10}$ no leste do Canadá, porque nós queríamos fazer algumas ligações. Nos demos conta de que, se a gente fizesse as coisas em pares, com um de dentro e o outro de fora, isso era muitíssimo melhor do que estando só um de nós.

9 Ver Eckert $(1989,2000)$.

10 A Acádia é a região cultural e histórica da América do Norte que diz respeito à colônia francesa com esse nome que fez parte da Nova França. Por vezes o referente são áreas de províncias do leste canadense e do estado do Maine nos Estados Unidos, por vezes, mais difusamente, à diáspora acadiana ou mesmo à francofonia norte-americana. 
Ruben Oliven: Mmhm.

Monica Heller: Porque, sabe, eu posso fazer uma pergunta idiota, porque eu não sei de nada, nunca estive aqui antes, e a Annette pode dizer: "Ah, é, eu também gosto disso", mas ela não pode fazer a mesma pergunta que eu posso, porque ela devia saber aquilo.

Ruben Oliven: Mmhm.

Monica Heller: Assim todas essas diferentes razões passaram a ser metodológicas, ou teórico-metodológicas, além de práticas.

Ruben Oliven: Mmhm.

Monica Heller: Para fazer trabalho em equipe. Então: trabalho em equipe. Distribuído espacialmente: muitas idas e vindas. Conexão: começa aqui e segue para lá; você se desloca para lá. Isso pode ser em termos de um conjunto de pessoas para outro ou de um lugar para outro. Assim eu passo muito tempo - o Canadá é grande - no avião, ou em trens e carros. Graças aos céus pelo Skype. Torna as coisas mais fáceis. Zoom é ainda melhor, por sinal. A internet facilitou as coisas também, mas eu me desloco bastante. A gente se desloca muito, tentando fazer com que os diferentes integrantes da equipe - assim, quando eu sou a investigadora principal, eu me certifico de que conheço todo o mundo e vejo tudo, mas a gente tenta garantir também que, por exemplo, alguém que está trabalhando principalmente em New Brunswick, a gente se certifica de que ao menos uma vez essa pessoa vai a Alberta para que possa ver.

Ruben Oliven: Mmhm.

Monica Heller: Nos reunimos no final do dia para discutir e escrever notas de campo em conjunto, lemos as notas de campo uns dos outros e discutimos. Circulamos transcrições. O Dropbox é uma ferramenta muito útil, para imagens também. Agora pela primeira vez temos um website, que foi projetado como um dos nossos produtos principais, porque estamos usando os casos de 
indivíduos em particular, e em alguns casos as quatro gerações das famílias deles, para demonstrar os tipos de mobilidades que são apagados pela construção de nação e como essas mobilidades são centrais para a possibilidade de sequer imaginar algo como uma nação. Assim temos um mapa interativo com todo o tipo de documentação que estamos montando no momento, o que é muito difícil, porque eu não sei como fazer isso.

Ruben Oliven: Mmhm.

Monica Heller: E também estamos num tipo de embate a respeito de como produzir conhecimento. Assim o trabalho de campo em equipe também é uma questão de produção de conhecimento em equipe. Fazemos muitos painéis e números especiais, de modo que todo o mundo pode participar. Um livro que escrevemos tem cinco autores em conjunto. ${ }^{11} \mathrm{E}$ o website é obviamente um empreendimento coletivo, muitas vezes parecido com dar nó em pingo d’água, nem sempre é tão fácil. Eu estou agora mais interessada em explorar algo que eu estou fazendo com a Sari [Pietikäinen] - estou trabalhando com ela no norte da Finlândia também - em tentar encontrar caminhos que não sejam esses livros lineares, ou artigos. Mas ao mesmo tempo estamos trabalhando com gente mais jovem, que precisa dessas coisas para os seus empregos e estabilidade. Tem gente confrontando as formas canônicas de produção de conhecimento, muitos no Canadá trabalhando com povos indígenas. Por isso acho que é um momento interessante, e é aí que eu fico também muito sensível a tudo isso, como editora do Journal of Sociolinguistics, uma revista acadêmica típica. E toda a história do acesso aberto tem a ver com isso. De certo modo, eu sinto às vezes que escorreguei ladeira abaixo, sabe? Comecei a fazer certas coisas por certas razões e acabei nesse mundo todo, sabe, de reimaginar a produção de conhecimento. Eu não vou fazer isso acontecer, e provavelmente isso não vai acontecer no meu período de vida, e eu estou num ponto na minha carreira em que posso experimentar certas coisas, mas não sobre as carreiras dos meus colegas.

11 Ver Heller et al. (2016). 
Pedro Garcez: Passando de questões metodológicas para questões programáticas, considerando que muitas vezes pode haver um abismo entre Linguística e Antropologia, como me parece ser o caso no ambiente acadêmico brasileiro, como é que você vê essa divisão de trabalho disciplinar, em especial no que diz respeito aos estudos linguagem?

Monica Heller: Eu mencionei antes os modos como para mim e para alguns dos meus colegas de geração na pós-graduação a divisão disciplinar entre Linguística e Antropologia tem sido problemática, para nós, nas nossas vidas. E mesmo entre Antropologia Linguística e Antropologia Sociocultural... Para muitos dos meus colegas, você menciona Antropologia Linguística, e eles dizem: "Uh, ih, dá medo." Tem alguma coisa em que a linguagem, a imagem da Linguística e da linguagem, tem sido muito influenciada pelo que tem sido - eu diria que agora são os últimos 150 anos - a extração da linguagem do mundo social. Um pouco disso aparece nesses tipos de divisas disciplinares. Eu acho que é mais uma questão de grau do que de natureza, isto é, que a questão da Antropologia línguo-sócio aparece como divisor interdisciplinar de muitos tipos diferentes de maneiras, mesmo em um departamento com quatro campos. Mas, também para colegas em lugares como o Brasil ou, digamos, como a França, as pessoas com quem eu tenho afinidade, que trabalham nas mesmas coisas que eu na França, eles estão em Sciences du Langage. Então as pessoas com quem eles têm que brigar são os gerativistas, os estruturalistas, os formalistas. A luta deles é: "Ei, tem algo de social a respeito desta coisa, a respeito do que vocês precisam prestar atenção." E isso se passa em todos os lados. Ou em lugares como a Espanha, ou a Alemanha, onde as coisas estão divididas em Filologias: você não pode trabalhar com bilinguismo francês-inglês porque ou bem você está em um Instituto de Anglística ou em um Instituto de Romanística, e eles estão em institutos diferentes. Isso é uma história real. Há todo tipo de maneira em que nós então, como Bonny McElhenny, com quem eu escrevi o livro Language, capitalism, colonialism, estamos tentando voltar para entender o que subjaz a isso. O que está em jogo, ou o que é para ser ganho com essa extração, da linguagem. Assim, não tenho tanta certeza de que se trata de o que os antropólogos e sociólogos perdem ao não olharem para a linguagem; mas sim de por que os especialistas da linguagem se agarram a essa coisa como perícia especializada que não vai ser 
compartilhada com mais ninguém. Por que é que isso é transformado em um objeto amedrontador, místico, que requer iniciação no culto da Linguística. Há muito a ser dito sobre isso. Parte tem a ver com algo a respeito do que a Bonny e eu falamos muito. ${ }^{12}$ Tem a ver com momentos em que houve um interesse em despoliticização. Há diferentes momentos em diferentes lugares. Para os Estados Unidos bem agora, acho que ainda estamos lidando com as consequências do macarthismo. Assim, a possibilidade de olhar para coisas como diferença social e desigualdade social foi exprimida da Linguística por meio da ordem a agentes do FBI para fazerem interrogatórios com linguistas. A preocupação com ser denunciado. Roman Jakobson foi denunciado pelo chefe de departamento dele em Harvard. Ao que parece houve um encontro, acho que foi da Associação Americana de Sociologia, possivelmente, em Toronto... Bom, há muito trabalho empírico a fazer sobre o que de fato se passou. E então a Guerra Fria, essa é uma coisa em particular a respeito de algo em particular - e os Estados Unidos, claro, se tornam o centro do universo em termos de produção de conhecimento... então, com o centro do universo despoliticizado, o resto do universo passa a ter um problema. Eu gostaria de entender melhor o que aconteceu na União Soviética, mas houve maneiras em que a intervenção de Stalin no campo da Linguística também teve um efeito de tipo semelhante, em uma espécie de modo paralelo em reverso. Tem havido muita pressão, certamente depois da Segunda Guerra Mundial, para despoliticizar pela via da tecnicização, pela via do estruturalismo, para dizer de modo demasiadamente simples. Para a tecnologia de computadores, entender as línguas foi particularmente interessante para desenvolver as tecnologias de computação, linguagens de computação, esses tipos de coisas, que estão, é claro, a serviço de objetivos políticos, mas que foram legitimados exatamente por não se dizer isso, certo? E assim há interesses em manter isso em silêncio, há interesses em manter essas coisas separadas. Portanto eu acredito que há razões por que isso vem sendo desafiado em particular agora. E a Linguística Aplicada, como um campo, realmente surgiu disso, certo? Surgiu de interesses militares por tradução e surgiu de interesses militares por aprendizagem de línguas, e de interesses militares em computação. E de fato há modos em que - no livro ${ }^{13}$

12 Ver Heller e McElhinny (2017).

13 Ver Heller e McElhinny (2017). 
eu traço uma espécie de história do esperanto desde o final do século XIX por aí. Hoje, mesmo uma área como o esperanto, que era para solucionar problemas de conflito, também foi entendida como um campo a ser compreendido tecnicamente. Como fazemos essa comunicação internacional multilíngue? Qual é a técnica melhor para isso? Vamos inventar línguas que sejam fáceis de aprender. Então precisamos ter um entendimento técnico da natureza da estrutura dessas línguas para podermos fazer isso. Portanto, há toda uma história da Linguística Aplicada que surge dessa tecnicização, e toda uma história da Antropologia, eu acho, que é sobre despoliticizar tudo isso. Então como é que vamos reunir tudo isso? Quer dizer, antes estávamos falando que seria, talvez, pela descoberta de estruturas universais subjacentes a tudo. É possível. Ou mantendo essas coisas em pistas paralelas, de certo modo como na tradição de Franz Boas. Ou eu talvez deva perguntar a vocês por que vocês acham que os antropólogos não procuraram tirar a linguagem dos linguistas, dizendo: "Olha, tudo é processo social. Tudo é prática social. Nós podemos usar as nossas ferramentas de compreensão dos processos sociais e das práticas sociais para compreender isso."

Pedro Garcez: Acho que no Brasil isso em certa medida já aconteceu.

\section{Monica Heller: OK.}

Pedro Garcez: Mas não em departamentos de Antropologia e não em institutos de Ciências Sociais.

\section{Monica Heller: Então onde?}

Pedro Garcez: Em Linguística Aplicada, no desenvolvimento brasileiro da Linguística Aplicada, como algo que é distinto da Linguística, e que é tão grande quanto.

Monica Heller: Claro, mas para mim isso não é um mistério. Isto é, à medida que o pessoal de linguagem foi fazendo o seu trabalho, primeiro você tem a coisa se fragmentando no que diz respeito ao problema do significado, e quando você começa com o problema do significado, você entra no problema 
da interação. Então há uma razão por que quando eu era estudante de pós-graduação em Berkeley, as pessoas que estavam interessadas em Pragmática Linguística estavam conversando com os cientistas cognitivos, que estavam falando com os filósofos da linguagem, que estavam falando com os antropólogos interacionistas. Então você tem um ramo da Linguística, na verdade eu diria um ramo da Linguística Aplicada, não da Linguística, se politicizando, de muitas maneiras diferentes. Eu encontrei isso na forma dos meus estudantes nos 1980 que tinham ido para a China. Eram falantes nativos de inglês, canadenses falantes nativos de inglês, recrutados para lecionar inglês na China, porque o sotaque canadense é o mais neutro, certo? Alguns deles só se divertiram. Alguns acordaram um dia na sua residência universitária se perguntando: "O que é que eu estou fazendo aqui? O que está acontecendo que me permite explicar por que nós estamos sendo recrutados para vir aqui? Ninguém está pedindo para os chineses virem até nós! Há algo a respeito do inglês que está se passando e que eu preciso entender." E aí eles decidem voltar para fazer pós-graduação e aparecem nas minhas aulas, e isso conduz a um conjunto de reflexões acerca do inglês na globalização e neocolonialismo, e assim por diante. Ou você encontra isso em Linguística em torno de pessoas que têm feito esse tipo de trabalho mais técnico, que os povos indígenas e inuit no Canadá entendem que tem sido um processo extrativo de descrição linguística. "Vamos escrever uma gramática. Vamos escrever um dicionário", isso então sendo reivindicado de modo a reivindicar a língua. "Assim vamos arrancar a língua de vocês nas escolas indígenas em regime de internato, ${ }^{14}$ mas queremos algum informante para podermos fazer a gramática." E aí eles se fortalecem o suficiente para poder dizer: "Não vamos mais jogar esse jogo. Isso é uma coisa política. Não venha me dizer que é puramente um exercício acadêmico, intelectual. Isso é político. É político para nós, e nós vamos tomar isso de volta." E assim você tem linguistas brancos confrontando isso e aprendendo a como ser aliados, mas reconhecendo que a Linguística em alguma forma é política. Assim, que os linguistas teriam que encarar as dimensões

14 Desde antes da sua plena constituição como tal, o Estado canadense instituiu um sistema de escolas em regime de internato para as populações indígenas, chamadas "residential schools", com o propósito de retirar os jovens indígenas do convívio familiar comunitário e promover a sua assimilação. A última escola desse tipo fechou em 1996. 
políticas - claro, não todos; alguns ainda seguem fazendo a coisa deles -, mas, que alguns linguistas seriam confrontados com isso e iriam seguir pela avenida da politicização, isso não me surpreende. O que não entendo tampouco - ou de todo, na verdade, agora que penso a respeito disso - é por que vários dos meus colegas na Antropologia Sociocultural, com quem eu compartilho tantos interesses, em torno de cidadania, por exemplo, se viram para mim com surpresa e dizem: "Ah, meu Deus, a gente devia conversar!"

\section{Ruben Oliven: [risos]}

Monica Heller: "Nós temos muitos interesses compartilhados! Eu achei que você fosse linguista." Bom, vai ver que eu sou uma péssima linguista.

\section{Ruben Oliven/Pedro Garcez/Monica Heller: [risos]}

Monica Heller: Sob certos termos eu sou realmente uma péssima linguista.

Pedro Garcez: Aqui nós somos vistos como algo que não é a coisa de verdade.

Monica Heller: Precisamente. Isso. Não ser a coisa de verdade. Com orgulho. Está bem assim. Eu encontrei um outro nicho, mas eu não entendo por que ainda é uma surpr - bom, uma parte que eu de fato entendo, e tivemos esta discussão na AAA, sabe, sobre o fato de que, para ser representativo, tem que ter um assento para os arqueólogos, e um assento para os antropólogos biológicos, e um assento para os socioculturais e dãdãdã... Mas, claro, tem, sabe, o quê? $66 \%$ da? 70\% dos associados são antropólogos socioculturais de um tipo ou outro. E todos os vários grupos baseados em identidades estão todos em Antropologia Sociocultural. Uns poucos estão em Antropologia Biológica, talvez um antropólogo linguístico. E ainda assim, as coisas estão igualmente distribuídas e tem... E a Antropologia Linguística realmente uma coisa diferente, a esta altura, neste ponto quase pós-boasiano. Ainda não chegamos lá, mas estamos em um momento do fim da Antropologia boasiana. Estou sendo injusta aqui, mas, enfim, me perdoem. Por que deveria haver qualquer diferença entre Antropologia Linguística e Antropologia Sociocultural? No nosso departamento na University of Toronto, nós temos os quatro programas diferentes, para os quais 
os estudantes têm que se inscrever separadamente. E, administrativamente, houve um pequeno pesadelo, e veio à tona a fusão entre o que é chamado no nosso departamento de Antropologia Evolucionária e Arqueologia, e Antropologia Linguística e Sociocultural. E houve muita resistência a isso por parte dos antropólogos linguistas, porque você ia perder controle sobre os recursos, você teria que competir com as pessoas da Sociocultural pelos mesmos recursos. Então, sim, há uma razão prática por que isso. Uma vez que você tem um campo, ele tem um nome, tem mercado atrelado a ele. Então eu entendo essa parte. A questão é mais, intelectualmente, por que pessoas interessadas em diferença social e desigualdade social não insistiriam que linguagem, comunicação, mais amplamente, está claramente em conexão com isso? Por que será? Eu acho que há maneiras em que - houve um tempo que em Sociologia era mais fácil, certo, fazer Etnometodologia.

Ruben Oliven: Mmhm.

Monica Heller: Ou coisas do tipo goffmaniano. Acho que está mais difícil agora.

Ruben Oliven: Mmhm.

Monica Heller: Mas, sim, então o que você acha?

Ruben Oliven: Acho que pode haver algumas razões. Uma é o que você menciona: você cria um domínio e você não quer que outras pessoas se metam na sua seara.

Monica Heller: É.

Ruben Oliven: A outra eu acho que tem a ver com o treinamento e mesmo o susto. Quer dizer, as coisas que os linguistas de verdade fazem são tão esotéricas, tão difíceis, que as pessoas dizem: "Bom, eu não consigo nem iniciar uma conversa." Então na verdade me parece que o que os antropólogos são capazes de fazer é conversar com pessoas como você, conversar com Todorov, ler Todorov.

Monica Heller: Mmhm. 
Ruben Oliven: E dizer: "Bem, esse é um linguista que eu sou mais ou menos capaz de entender." É como com os cientistas políticos. Há alguns cientistas políticos que você, que eu sou capaz de entender, e outros... eu acho - quer dizer, eu não compro todos, mas também a técnica que eles usam se torna quase esotérica. Então eu acho que as pessoas ficam com medo disso. Em segundo lugar, há pouco treinamento.

Monica Heller: Mmhm.

Ruben Oliven: Ao menos no Brasil, já que não temos os quatro campos.

Monica Heller: É mesmo. Mas é um círculo vicioso.

Ruben Oliven: É um círculo vicioso, sim, com certeza. "Não é com isso que eu trabalho, eu não sei trabalhar com isso", o que é um absurdo.

Monica Heller: Exato. Precisamente. Então, sabe, em certo sentido, o que alguns de nós estamos tentando fazer é dizer: "Olha, se nós vamos argumentar que o processo social é em grande medida comunicativo..."

Ruben Oliven: Mmhm.

Monica Heller: “... nós temos que conversar uns com os outros." Isso não faz nenhum sentido. Uma das razões pelas quais eu me sinto mais à vontade com antropólogos do que com linguistas - não há dúvida a esse respeito - e é uma das razões por que eu me autodisciplinei ao me botar num departamento de Linguística, porque assim eu ia ter que, sabe, aprender aquela coisa. Mas eu não sou mais esperta do que qualquer outra pessoa, certo?

Ruben Oliven: Mmhm.

Monica Heller: Talvez eu tenha uma tendência à resolução de problemas que, sabe, essa coisa demanda, mas, sabe, para mim, por mais agradável que tenha sido passar uma tarde de sexta-feira no meu dormitório universitário produzindo árvores de estrutura profunda, isso não ia me levar aonde eu precisava ir. 
Ruben Oliven: Mmhm.

Monica Heller: Então, ainda que o treinamento em muitos aspectos me tenha sido útil, e a apresentação à materialidade da linguagem, à substância sonora da linguagem, isso foi extremamente útil para mim. Mas, sabe, eu costumava ir a uma gama muito mais ampla de congressos, e há muitos aos quais eu não vou mais, simplesmente porque essencialmente eu me tornei mais e mais e mais por assim dizer uma antropóloga sociocultural e menos e menos e menos uma linguista. Então, para mim, são frutos à disposição, estão ali para serem apanhados. Eu não sei quem lê as minhas coisas em outras partes do $\mathrm{m}$ - quer dizer, eu sei que eu chego lá pelos canais disciplinares de praxe, certo?

\section{Ruben Oliven: Mmhm.}

Monica Heller: Assim, na França são as pessoas que estão brigando com os gerativistas e que na verdade são altamente politicizadas. Temos todo um movimento sobre a politicização do campo dos estudos da linguagem. Bom, por exemplo, Elvira Arnoux, em Buenos Aires, vem de... o quê? Não da Antropologia, isso é certo. Assim, há esses pequenos recantos interessantes. Mas me parece que eles sempre são não Antropologia. E há algo a pensar por aí.

Ruben Oliven: Esta universidade, a UFRGS, é interessante, porque - em 1937 no Brasil foi implantada uma ditadura, que se estendeu até 1945, e um dos primeiros decretos ditou que ficava proibido falar qualquer língua que não o português em espaços públicos, o que neste estado teve um efeito muito forte.

Monica Heller: Claro.

Ruben Oliven: Por conta disso, os descendentes de alemães e italianos, os dois grupos principais de imigrantes, não podiam mais ter suas escolas em suas línguas, não podiam mais ter culto religioso nessas línguas, nem sequer lápides de túmulos. Nesta universidade, há vários docentes e funcionários que aprenderam, como primeira língua, alemão, hunsrück ou talian, e que 
aprenderam português quando foram para a escola. Eles não são sabem escrever ou a gramática de maneira sistemática, mas isso ainda existe, quer dizer, ainda tem gente que fala essas línguas, e isso, quer dizer, foi uma enorme violência simbólica que foi feita contra eles. E o que é mais, os três principais grupos de imigrantes eram os alemães, os italianos e os japoneses, mais em São Paulo do que aqui...

Monica Heller: Claro.

Ruben Oliven: ... e eles eram os inimigos que o Brasil estava combatendo, porque em 1942 o Brasil entrou na Guerra, então havia toda uma questão política.

Monica Heller: Mas, e eu acho, sabe, que tem toda uma gama de coisas que você pode fazer sendo um ditador.

Ruben Oliven: Mmhm.

Monica Heller: Por que escolher língua? O que é que faz com que esteja disponível como modo de exercício de violência simbólica?

Ruben Oliven: Mmhm.

Monica Heller: Então.

Ruben Oliven: Foi chamada de Campanha da Nacionalização, era preciso brasileirar o povo.

Pedro Garcez: E a questão atual mais candente em termos de linguagem e desigualdade social no Brasil tem pouco a ver com...

Monica Heller: Multilinguismo.

Pedro Garcez: ... com outras línguas, ou multilinguismo, e tem, sim, a ver com variação em português, e essa é inteiramente uma questão sociocultural que é disputada e posta em prática na verdade pela linguagem, certo? 
Monica Heller: Então eu insisto em colocar no mesmo quadro qualquer coisa que não seja uma linguagem monolíngue padronizada. Por isso eu fico tão focada no Estado-nação, certo?

Ruben Oliven: Mmhm.

Monica Heller: Essa é a base ideológica...

Ruben Oliven: Mmhm.

Monica Heller: ... para isso, e assim temos que explicar o Estado-nação e o que essa ideologia do espaço monolíngue padronizado faz e que produz como problema qualquer coisa que não caiba nessa caixa.

Ruben Oliven: Existem quase 200 línguas diferentes faladas no Brasil.

Monica Heller: Pois.

Ruben Oliven: E o primeiro deputado indígena na Câmara de Deputados foi um homem chamado Juruna, um cacique xavante, e assim xavante era a língua nativa dele, e ele falava um português que não era tão bom, e então pediu permissão para falar na língua dele, e disseram: "Não, porque a língua oficial do Brasil conforme a Constituição é o português, então você não pode falar em xavante." E assim ele teve que falar em português e fez um discurso dizendo que todos os ministros de Estado eram ladrões. Tenho certeza de que boa parte da população concordaria, mas, quer dizer, se ele dominasse mais o português, ele diria "as pessoas dizem que", mas, como ele afirmou aquilo como verdade, decidiram processá-lo. A coisa toda terminou à brasileira, quer dizer, deram um jeito. Mas isso mostra que o Brasil não estava pronto para permitir que uma pessoa fale numa língua que era falada muito antes de os portugueses chegarem aqui, muito antes de haver Brasil. Nem sequer havia Brasil.

Monica Heller: Mas e tem, mas tem também... isto... vou dizer algo que me faz muito impopular toda vez, e eu digo o tempo todo. Então, essa noção de língua xis, língua nomeada, também é um produto do Estado-nação... 
Ruben Oliven: Mmhm.

Monica Heller: ... e, assim, uma das questões em torno das línguas das minorias, de qualquer tipo, é que você está fazendo violência simbólica contra alguém porque você está decidindo que tal coisa vai estar na língua e tal outra coisa não vai estar na língua. Nas escolas onde eu estava passando muito tempo, havia professores dizendo para as crianças: "Vocês nem sequer falam a língua de vocês direito!"

Pedro Garcez: Que é uma coisa comum...

Ruben Oliven: É.

Pedro Garcez: ... que é dita...

Ruben Oliven: Nas escolas, sim.

Monica Heller: Certo.

Pedro Garcez: ... para a maioria da população brasileira.

Monica Heller: E não há razão clara por que chamar um filme de "vu" em vez de "film" não é francês.

Ruben Oliven: Mmhm.

Monica Heller: Certo?

Ruben Oliven: Mmhm.

Monica Heller: Ou dizer... A sanitarização é prática violenta, seja, sabe... de qualquer maneira. Então isso se torna muito difícil quando pessoas minoritarizadas, gente que é minoritarizada por conta de falar uma língua diferente, tomam para si a noção de língua padronizada para lutar em contra-ataque. Esse é um embate que eu tenho no Canadá, certo? 
Ruben Oliven: Mmhm.

Monica Heller: O francês não é uma coisa; o inglês não é uma coisa. São coisas que a gente inventou. $\mathrm{E}$ os franco(-canadenses) estão lutando contra uma posição de desigualdade como uma nação que tem direitos com relação aos anglo(-canadenses). Mas, se você diz: "Nós somos uma nação delimitada com uma língua delimitada", então você vai ter que começar a ter que policiar uns aos outros, certo?

Ruben Oliven: Mmhm.

Monica Heller: E daí você começa com essa história de "vocês nem sequer falam a língua de vocês!..."

Ruben Oliven: Claro.

Monica Heller: “... direito”, o que por sua vez reproduz as mesmas relações de desigualdade, até onde eu consigo entender.

Ruben Oliven: E se você quiser ver as coisas no outro lado, esta universidade agora quer ser uma universidade de classe mundial. Todo o mundo quer ser uma universidade de classe mundial, mas até recentemente você só podia redigir uma tese de doutorado ou uma dissertação de mestrado em português, porque alguém consultou os advogados da universidade...

Monica Heller: Ahn han.

Ruben Oliven: ... e eles disseram: "Bem, uma tese é um documento oficial, e nossa Constituição diz que português é a língua oficial do Brasil. Logo, documentos oficiais só podem ser redigidos em português." Agora mudaram isso, e pode ser em espanhol, inglês e francês, eu acho, mas levou um longo tempo. Alguém se deu conta, "nós queremos ser globais, então nós temos que aceitar".

Monica Heller: É, é. 
Ruben Oliven: Então mudaram a interpretação da Constituição.

Monica Heller: Isso. Então é aí que surge a pergunta de interesse, que é: Não era OK em 1995, então o que está acontecendo agora?...

Ruben Oliven: Exatamente.

Monica Heller: ... que faz com que você tenha que voltar e repensar isso? Então a coisa que era um problema enorme há 50 anos agora é uma coisa boa. Mas, sabe, mesmo nesse caso, está claro que não se trata de uma coisa boa inequivocamente.

Ruben Oliven: Mmhm.

Monica Heller: Há partes disso que são boas, e outras...

Ruben Oliven: Mmhm.

Monica Heller: Então há certos tipos de multilinguismos que são uma coisa boa; outros tipos de bilinguismo, multilinguismo ainda não são OK, e a variação linguística de certo modo é varrida para baixo do tapete.

Ruben Oliven: Você tem mais perguntas?

Pedro Garcez: Não, acho que estamos sem tempo.

Ruben Oliven: Você quer acrescentar alguma coisa?

Monica Heller: Não, isso foi divertido.

Ruben Oliven: Foi ótimo.

Monica Heller: Obrigada.

Ruben Oliven: Muito obrigado. 


\section{Referências}

AMERICAN ANTHROPOLOGICAL ASSOCIATION. Resolution calling for boycott of Israeli academic institutions to be placed on AAA spring ballot. 21 nov. 2015. Disponível em: https://www.americananthro.org/StayInformed/NewsDetail. aspx? ItemNumber=13213. Acesso em: 15 maio 2019.

AMERICAN ANTHROPOLOGICAL ASSOCIATION. Reasons to vote "Yes" on the AAA resolution to boycott Israeli academic institutions. 8 abr. 2016a. Disponível em: https://www.americananthro.org/StayInformed/NewsDetail. aspx?ItemNumber=13489\#Reasons_Yes. Acesso em: 15 maio 2019.

AMERICAN ANTHROPOLOGICAL ASSOCIATION. Reasons to vote "No" on the AAA resolution to boycott Israeli academic institutions. 8 abr. 2016b. Disponível em: https://www. americananthro.org/StayInformed/NewsDetail.aspx?ItemNumber=13489\#Reasons_ No. Acesso em: 15 maio 2019.

AMERICAN ANTHROPOLOGICAL ASSOCIATION. AAA votes down academic boycott resolution. 7 jun. 2016c. Disponível em: https://www.americananthro.org/StayInformed/NewsDetail.aspx?ItemNumber=14768. Acesso em: 15 maio 2019.

ECKERT, P. Jocks and burnouts: social categories and identity in the High School. New York: Teachers College Press, 1989.

ECKERT, P. Linguistic variation as social practice: the linguistic construction of identity in Belten High. Malden: Blackwell, 2000.

HELLER, M. Linguistic minorities and modernity: a sociolinguistic ethnography. London: Longman, 1999.

HELLER, M. The commodification of language. Annual Review of Anthropology, v. 39, p. 101-114, 2010.

HELLER, M. Paths to post-nationalism: a critical ethnography of language and identity. Oxford: Oxford University Press, 2011.

HELLER, M.; DUCHÊNE, A. Pride and profit: changing discourses of language, capital and nation-state. In: DUCHÊNE, A.; HELLER, M. (ed.). Language in late capitalism: pride and profit. New York: Routledge, 2012. p. 1-21.

HELLER, M.; DUCHÊNE, A. Treating language as an economic resource: discourse, data and debate. In: COUPLAND, N. (ed.). Sociolinguistics: theoretical debates. Cambridge: Cambridge University Press, 2016. p. 139-156. 
HELLER, M.; McELHINNY, B. Language, capitalism, colonialism: toward a critical history. Toronto: University of Toronto Press, 2017.

HELLER, M. et al. Sustaining the nation: the making and moving of language and nation. New York: Oxford University Press, 2016.

WOLF, E. A Europa e os povos sem história. Trad. E. M. de Moura. São Paulo: EdUSP, 2009.

Recebido:17/10/2019 Aceito:14/11/2019 | Received:10/17/2019 Accepted:11/14/2019 